\title{
Galectin-1-mediated cell adhesion, invasion and cell death in human anaplastic large cell lymphoma: Regulatory roles of cell surface glycans
}

\author{
OSAMU SUZUKI and MASAFUMI ABE \\ Department of Diagnostic Pathology, School of Medicine, Fukushima Medical University, Fukushima 960-1295, Japan
}

Received December 6, 2013; Accepted January 28, 2014

DOI: $10.3892 /$ ijo.2014.2319

\begin{abstract}
Galectin-1 is known to be one of the extracellular matrix proteins. To elucidate the biological roles of galectin-1 in cell adhesion and invasion of human anaplastic large cell lymphoma, we performed cell adhesion and invasion assays using the anaplastic large cell lymphoma cell line H-ALCL, which was previously established in our laboratory. From the cell surface lectin array, treatment with neuraminidase from Arthrobacter ureafaciens which cleaves all linkage types of cell surface sialic acid enhanced Arachis hypogaea (PNA), Helix pomatia (HPA) and Phaseolus vulgaris-L (L-PHA) lectin binding reactivity to cell surface of lymphoma cells suggesting that neuraminidase removes cell surface sialic acid. In cell adhesion and invasion assays treatment with neuraminidase markedly enhanced cell adhesion to galectin-1 and decreased cell invasive capacity through galectin-1. $\alpha 2,6$-linked sialic acid may be involved in masking the effect of the interaction between galectin-1 and cell surface glycans. H-ALCL cells expressed the $\beta$-galactoside- $\alpha 2,6$-sialyltransferase ST6Gal1. On resialylation assay by recombinant ST6Gal1 with CMP-Neu5Ac, $\alpha 2,6$ resialylation of L-PHA reactive oligosaccharide by ST6Gal1 resulted in inhibition of H-ALCL cell adhesion to galectin-1 compared to the desialylated H-ALCL cells. On knockdown experiments, knockdown of ST6Gal1 dramatically enhanced cell adhesion to galectin-1. N-glycosylation inhibitor swainsonine treatment resulted in enhancement of cell adhesion to galectin-1. In glycomic analysis using the lectin blocking assay treatment with PNA, Artocarpus integrifolia (Jacalin), Glycine max (SBA), Helix pomatia (HPA), Vicia villosa (VVA), Ulex europaeus (UEA-1), Triticum vulgaris (WGA), Canavalia ensiformis (ConA), Phaseolus vulgaris-L (L-PHA), Phaseolus vulgaris-E4 (E-PHA), Datura stramonium (DSA) lectins resulted in modulation of lymphoma cell to galectin-1 suggesting that several types of glycans may regulate cell adhesion to galectin-1 by steric
\end{abstract}

Correspondence to: Dr Osamu Suzuki, Department of Diagnostic Pathology, School of Medicine, Fukushima Medical University, 1 Hikarigaoka, Fukushima 960-1295, Japan

E-mail: osuzuki@fmu.ac.jp

Key words: galectin-1, glycosylation, sialic acid, sialyltransferase, cell adhesion, cell death, lectin array hindrance. The adhesive capacity of H-ALCL cells is regulated by phosphatidylinositol 3 phosphate kinase (PI3K) and actin cytoskeleton, and the invasive capacity of H-ALCL cells is regulated by PI3K, mitogen-activated protein kinase (MAPK), Rho and actin cytoskeleton. Furthermore, galectin-1-induced cell death in H-ALCL cells was accompanied by inhibition of CD45 protein tyrosine phosphatase (PTP) activity. In conclusion, cell adhesion and invasion to galectin-1 appeared to be regulated by cell surface sialylation and N-glycosylation, and galectin-1 regulates cell death through inhibition of CD45 PTP activity of H-ALCL.

\section{Introduction}

Galectin-1 is expressed in anaplastic large cell lymphoma (ALCL) as well as Hodgkin lymphoma (HL) (1). However, the biological significance of galectin-1 still remains unclear. Galectin-1 is known to induce cell death in human lymphoma and $\mathrm{T}$ cells (1-3). Galectins act as many biological functional molecules (4). Galectin-1 exists in serum and deposits to extracellular matrix (5). In addition, galectin-1 regulates cell adhesion of ovarian cancer cells (6). Cell surface sialic acid appeared to modulate cell adhesive capacity of lymphoma cells (7). In this study, we analyzed cell adhesive and invasive capacity to galectin-1 using human ALCL cell line to clarify the biological roles of galectin-1 in ALCL. We applied the cell surface lectin array in analysis of cell surface glycan modifications (8).

\section{Materials and methods}

Cell line. Human anaplastic large cell lymphoma cell line, H-ALCL was established in our laboratory. The H-ALCL cells were grown in the culture medium of RPMI-1640 containing $15 \%$ fetal calf serum in $5 \% \mathrm{CO}_{2}$ at $37^{\circ} \mathrm{C}$. The $\mathrm{H}-\mathrm{ALCL}$ cell line expresses the galectin-1 receptors, CD45RA [(leukocyte common antigen (LCA)] and CD45RO (UCHL-1) on the flow cytometric analysis (data not shown).

Cell surface lectin array analysis. We applied the cell surface lectin array analysis to detecet the cell surface glycosylations according to Landemarre et al with several modifications (8). The H-ALCL cells were treated with or without neuraminidase from Arthrobacter ureafaciens (no. 10269611001, Roche, 
Germany) at $0.2 \mathrm{U} / \mathrm{ml}$, at $37^{\circ} \mathrm{C}$ for $30 \mathrm{~min}$, then the cells were cytospun and cytospin cell preparations were stained by PNA lectin as described previously (9). Arachis hypogaea (PNA), Artocarpus integrifolia (Jacalin), Glycine max (SBA), Helix pomatia (HPA), Vicia villosa (VVA), Ulex europaeus (UEA1), Triticum vulgaris (WGA), Canavalia ensiformis (ConA), Phaseolus vulgaris-L (L-PHA), Phaseolus vulgaris-E4 (E-PHA), Datura stramonium (DSA) lectins were from EY Laboratory. The 96-well plate was coated by each lectin and air-dried. The neuraminidase treated or non-treated H-ALCL lymphoma cells $\left(1 \times 10^{6} / 2 \mathrm{ml}\right)$ were applied to each well (100 $\mu \mathrm{l} /$ well) and incubated at $37^{\circ} \mathrm{C}$ for $60 \mathrm{~min}$. After aspiration of the medium, PBS was added to each well and then aspirated to remove non-adhered cells. Then $100 \mu \mathrm{l}$ of $3.7 \%$ formaldehyde was added to each well to fix the adhesive cells at RT for $40 \mathrm{~min}$. After aspiration of formaldehyde, $100 \mu \mathrm{l}$ of $0.1 \%$ crystal violet was added to each well and the plates were incubated at RT for $40 \mathrm{~min}$. After washing twice, $100 \mu \mathrm{l}$ of $10 \%$ acetic acid was added to each well and the absorbance at 570-655 or $570 \mathrm{~nm}$ was determined using an ELISA plate reader (7). To analyze the effect of O-glycosylation cells were treated with the $\mathrm{O}$-glycosylation inhibitor benzyl 2-acetamido2-deoxy-3-O- $\beta$-D-galactopyranosyl - $\alpha$-D-galactopyranoside (benzyl- $\alpha$-GalNAc B5019, Sigma) (BZ) at a concentration of $2 \mathrm{mM}$ in culture medium for $72 \mathrm{~h}$ at $37^{\circ} \mathrm{C}$. To analyze the effect of $\mathrm{N}$-glycosylation cells were treated with the $\mathrm{N}$-glycosylation inhibitor SW at a concentration of $1 \mu \mathrm{g} / \mathrm{ml}$ in culture medium for $96 \mathrm{~h}$ at $37^{\circ} \mathrm{C}$. BZ treated or non-treated H-ALCL lymphoma cells $\left(1 \times 10^{6} / 2 \mathrm{ml}\right)$ were applied to each well $(100 \mu \mathrm{l} /$ well $)$, or SW treated or non-treated H-ALCL lymphoma cells $\left(2 \times 10^{6} / 2 \mathrm{ml}\right)$ were applied to each well $(100 \mu \mathrm{l} /$ well) and incubated as described above.

Cell adhesion assay. Tissue culture plates with 96-wells were coated with bovine splenic galaptin (a synomym of galectin-1, Sigma, G8777) (10 $\mu \mathrm{g} /$ well) or human recombinant galectin-1 (ATGP0385, ATGen Co. Ltd.) (10 $\mu \mathrm{g} /$ well) and dried at room temperature overnight. Each well was washed with $100 \mu \mathrm{l}$ PBS and was filled with RPMI-1640 containing 15\% bovine serum albumin (BSA) $15 \%$ FCS and the plates were incubated at $37^{\circ} \mathrm{C}$ for $60 \mathrm{~min}$. After aspiration of the medium, H-ALCL cells with or without neuraminidase (from Arthrobacter ureafaciens (AU): final concentration $0.2 \mathrm{U} / \mathrm{ml}$, at $37^{\circ} \mathrm{C}$ for $30 \mathrm{~min}$, a2,3-neuraminidase (BioLabs, P0728S, 50,000 U/ml): final concentration $0.2 \mathrm{U} / \mathrm{ml}$, at $37^{\circ} \mathrm{C}$ for $30 \mathrm{~min}$, neuraminidase from Newcastle disease virus (NDV): $0.2 \mathrm{U} / \mathrm{ml}$, Prozyme, at $37^{\circ} \mathrm{C}$ for $30 \mathrm{~min}$ ) treatment were added to each well and incubated at $37^{\circ} \mathrm{C}$ for $1 \mathrm{~h}$. After aspiration of the medium, PBS was added to each well and then aspirated to remove non-adhered cells. Then $100 \mu 1$ of $3.7 \%$ formaldehyde was added to each well to fix the adhesive cells at RT for $40 \mathrm{~min}$. After aspiration of formaldehyde, $100 \mu \mathrm{l}$ of $0.1 \%$ crystal violet was added to each well and the plates were incubated at RT for $40 \mathrm{~min}$. After washing with PBS, $100 \mu \mathrm{l}$ of $10 \%$ acetic acid was added to each well and the absorbance at 570-655 nm or $570 \mathrm{~nm}$ was determined using an ELISA plate reader (7). To analyze the effect of $\mathrm{O}$-glycosylation and $\mathrm{N}$-glycosylation cells are treated with $\mathrm{O}$-glycosylation inhibitor $\mathrm{BZ}$ and $\mathrm{N}$-glycosylation inhibitor SW as described above. To analyze the steric hindrance of $\mathrm{N}$-glycosylation in cell adhesion to galectin-1, we performed lectin blocking assay in galectin-1 adhesion assay. To analyze involvement of anaplastic large cell lymphoma kinase (ALK), CD30, CD45, CD45RO, epithelial membrane antigen (EMA) in cell adhesion to galectin-1, we carried out the inhibition assay using anti-ALK (ALK1, Dako, M7195), CD30 (BerH2, Dako, M0751), CD45 [leukocyte common antigen (LCA), Nichirei, H0108, Japan], CD45RO (UCHL-1, Dako, M0742), EMA (E29, Dako, M0613) antibody on galectin-1 adhesion assay. For isotype control experiment, the mouse IgG isotype control antibody (BD Pharmingen, no. 554721) was used. These antibodies were used as $5 \mu \mathrm{l}$ in $1 \mathrm{ml}$ cell suspension. ALK, CD30, CD45, CD45RO and EMA are expressed on the cell surface of H-ALCL cells determined by flow cytometric analysis (data not shown). Anti-CD30, CD45, CD45RO and EMA antibodies enhanced cell adhesion to galectin-1 suggesting that the protein portion of these molecules may be involved in the interaction between galectin-1 (in our preliminary data, not shown).

On the resialylation assay, the H-ALCL cells were desialylated by neuraminidase treatment and then, the cells were resialylated by recombinant ST6Gal1 (R\&D Systems, 5924-GT) at a condition ST6Gal1 $5 \mu \mathrm{g} / 100 \mu \mathrm{l}$ with CNP-Neu5Ac (Sigma, C8271) $1 \mathrm{mM}$, at $37^{\circ} \mathrm{C}$ for $120 \mathrm{~min}$.

Knockdown of ST6Gall. In order to analyze the regulatory mechanism of cell surface sialylation by ST6Gal1, siRNA transfection was performed as described previously with several modifications (25). For transfection, INTERFERin (Polyplus transfection, USA) was used according to the manufacturer's instructions. For knockdown experiments, siRNA (cat. no. 12842 called Type 42, sense: AGACAGUUUGUACA AUGAAtt, antisense: UUCAUUGUACAAACUGUCUtt, or cat. no. s12843 called Type 43, sense: ACCACUCAGAUAU CCCAAAtt, antisense: UUUGGGAUAUCUGAGUGGUat, Ambion Japan) was used. For control experiments, Ambion Silencer ${ }^{\mathrm{TM}}$ select negative control no. 1 siRNA (cat. no. 4390843) was applied. After 24-h incubation, the immunohistochemical staining was performed by anti-ST6Gal1 antibody (dilution x100, R\&D Systems, AF5924) and knockdown effect was validated by inhibition of ST6Gall protein expression in the cytoplasm of H-ALCL cells (9).

Invasion assay. The invasion assay (haptotaxis) was performed based on the methods of Albini et al (10) with several modifications. The 24-well culture plate was filled with $600 \mu 1$ the culture medium RPMI-1640 containing 15\% BSA 15\% FCS. The lower surfaces of the membranes of transwell chamber, chemotaxicell (Krabo, Japan) with an $8-\mu \mathrm{m}$ pore membrane were coated with $10 \mu \mathrm{l}$ galectin-1 $(1.0 \mathrm{mg} / \mathrm{ml}$, ATGen, no. ATGP0385) and dried at RT. Then coated chemotaxicells were inserted into each well. H-ALCL cells, $100 \mu \mathrm{l}$ of $2.4 \times 10^{6} / \mathrm{ml}$, were inserted into each chemotaxicell and incubated at $37^{\circ} \mathrm{C}$ for $24 \mathrm{~h}$. After incubation, the invaded cells at lower level of each well were counted by trypan-blue exclusion methods. The cell count was performed using duplicate wells with two experiments $(n=4)$, or triplicate wells with at least two independent experiments. On preliminary assay the amount of invaded cells in non-coating chemotaxicell was more than that in galectin-1 coating chemotaxicell (data not shown) suggesting that H-ALCL cells can invade to lower chamber through cell 

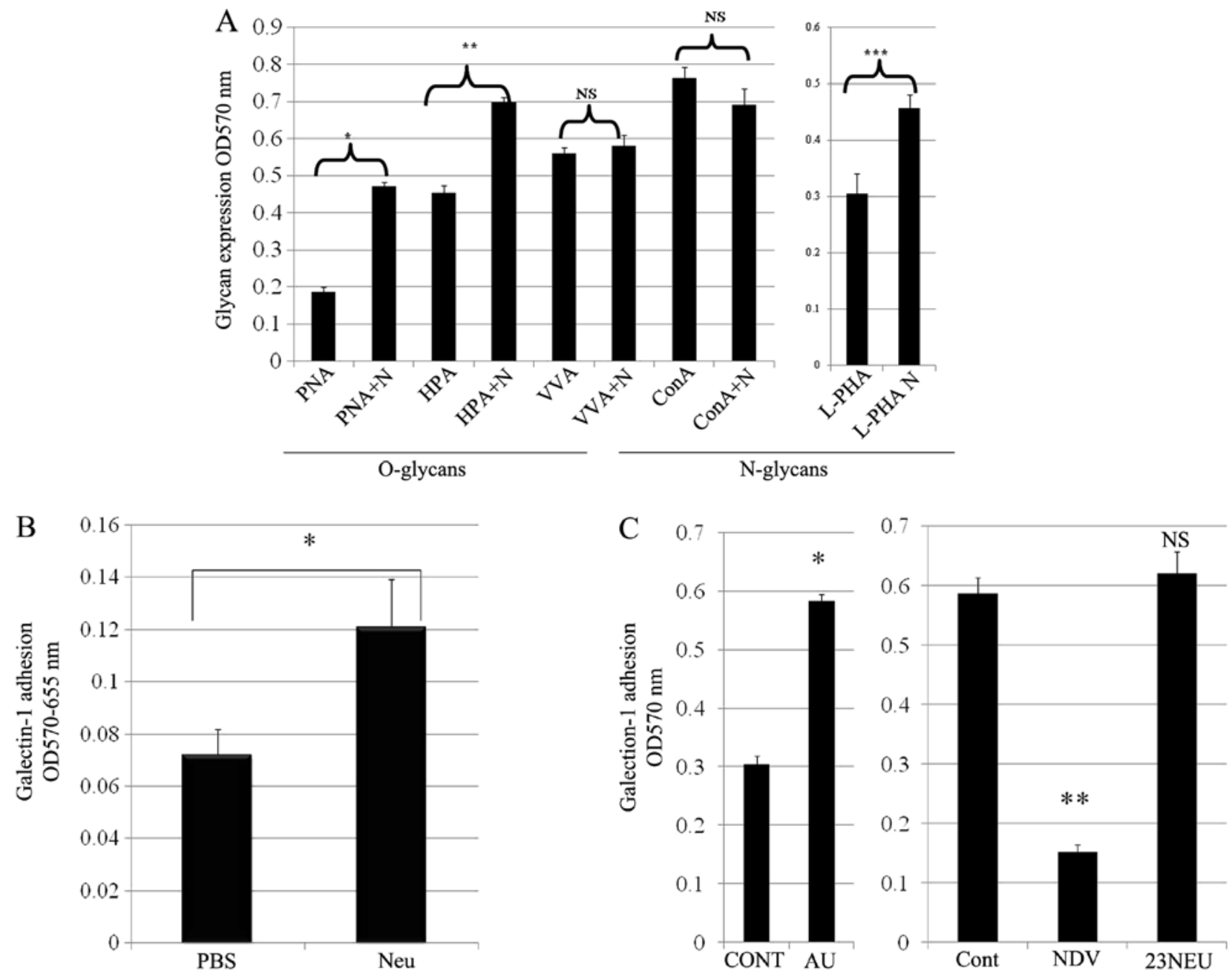

Figure 1. The treatment of neuraminidase which cleaves cell surface sialic acid enhanced PNA, HPA and L-PHA lectin reactivity suggesting that neuraminidase removes cell surface sialic acid from $\mathrm{O}$ - or $\mathrm{N}$-glycans (PNA, $\left.{ }^{*} \mathrm{P}<0.00001 ; \mathrm{HPA},{ }^{* *} \mathrm{P}<0.0001 ; \mathrm{L}-\mathrm{PHA},{ }^{* * *} \mathrm{P}=0.002\right)$. N, neuraminidase pre-treatment $(\mathrm{A})$. Treatment of neuraminidase markedly enhanced cell adhesion to galectin-1 (using galaptin) $\left({ }^{*} \mathrm{P}<0.0009\right)$. Neu, neuraminidase pre-treatment $(\mathrm{B})$. Treatment of neuraminidase from Arthrobacter ureafaciens markedly enhanced cell adhesion to galectin-1 (using recombinant galectin-1). Treatment of Newcastle disease virus neuraminidase dramatically inhibited cell adhesion to galectin-1 and $\alpha 2,3$ neuraminidase did not enhance cell adhesion to galectin- $1(\mathrm{C})\left({ }^{*} \mathrm{P}=0.0000069\right.$; ${ }^{* *} \mathrm{P}=0.0001$; NS, not significant). AU, neuraminidase from Arthrobacter ureafaciens; NDV, neuraminidase from Newcastle disease virus; 23 NEU, $\alpha 2,3$ specific neuraminidase.

contact to galectin-1 matrix component. To analyze the effect of cell surface sialylation, H-ALCL cells were treated with neuraminidase from Arthrobacter ureafaciens (AU) (final concentration $0.2 \mathrm{U} / \mathrm{ml}$ ) at $37^{\circ} \mathrm{C}$ for $30 \mathrm{~min}$. For analysis of phosphatidylinositol 3 kinase (PI3K) inhibitor, wortmannin (681675, Calbiochem) and mitogen-activated protein kinase (MAPK) inhibitor, PD98059 (513000, Calbiochem) or Rho inhibitor (C3 transferase) cells were pre-incubated with wortmannin at $1.7 \mu \mathrm{M}$ or PD98059 at $25 \mu \mathrm{M}$ for $30 \mathrm{~min}$, or $\mathrm{C} 3$ transferase at $2.0 \mu \mathrm{g} / \mathrm{ml}, 2 \mathrm{~h}$. Then the cell adhesion assay or invasion assay were performed. We confirmed the expression of PI3K, MAPK and Rho in the tumor cells of H-ALCL on immunohistochemical staining (data not shown). For analysis of cytochalasin B (Sigma), cells were pre-treated with cytochalasin $\mathrm{B}$ at $4 \mu \mathrm{M}$ for $30 \mathrm{~min}$.

Galectin-1 and ST6 Gall expression. H-ALCL cells were cytospun to the slide glass and the specimen was fixed with $100 \%$ alcohol. The immunohistochemical staining by antigalectin-1 antibody (100X dilution, Santa Cruz, clone S-14) or anti-ST6Gal1 antibody (100X dilution, R\&D Systems, AF5924). Then, the preparations were incubated with biotinylated anti-goat immunoglobulin. After washing in PBS three times, the preparations were incubated at room temperature for 20 min with avidin-biotin peroxidase complex kit (Dako, Tokyo, Japan). Then, they were incubated for $5 \mathrm{~min}$ at room temperature with diaminobenzidine (DAB) $-\mathrm{H}_{2} \mathrm{O}_{2}$ solution (60 $\mu \mathrm{g}$ DAB in $150 \mathrm{ml}$ PBS). The preparations were counterstained with hematoxylin and mounted.

Galectin-1 detection by ELISA. The supernatant of the conditioned culture medium in H-ALCL was prepared by centrifugation at $11,000 \mathrm{rpm}$, for $20 \mathrm{~min}$, at $4^{\circ} \mathrm{C}$. Galectin- 1 was measured by ELISA assay kit (USCN Life Science Inc. E9032 $\mathrm{Hu}$ ) according to the manufacturer's instructions.

Cell death induction and CD45 activity assay by galectin-1 treatment. The H-ALCL cells were treated with or without $12 \mu \mathrm{M}$ galectin- 1 for $72 \mathrm{~h}$. Then the number of viable cells was counted by trypan-blue exclusion test. We analyzed the CD45 

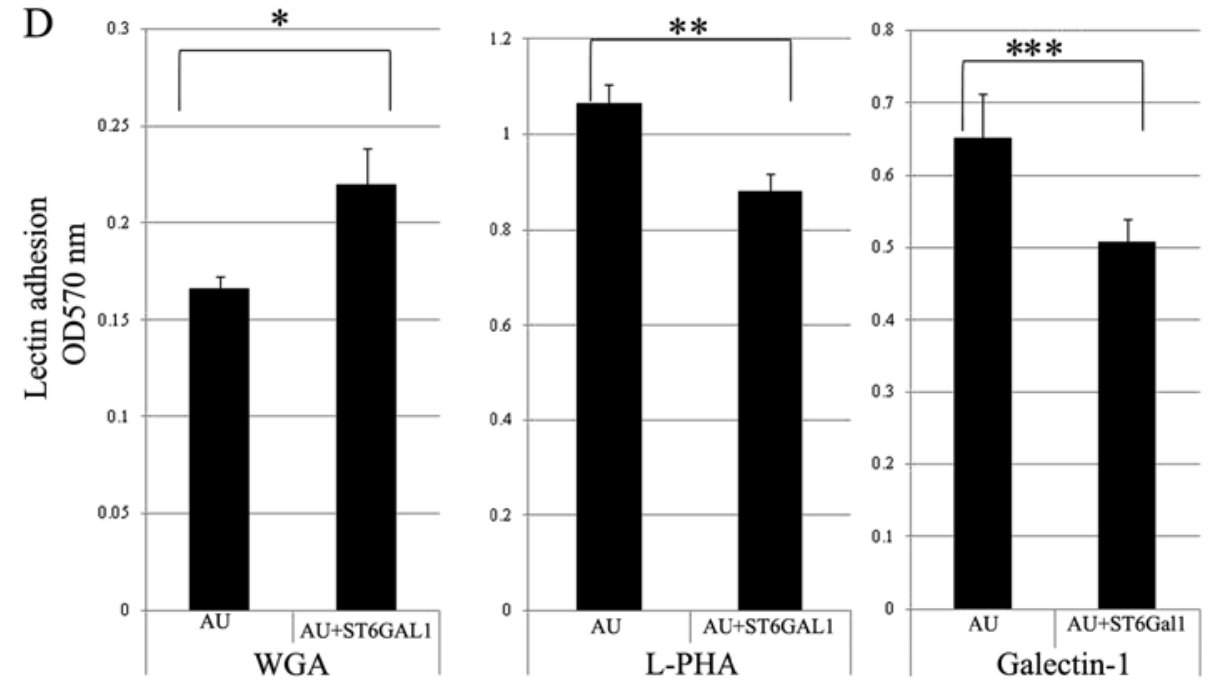

E
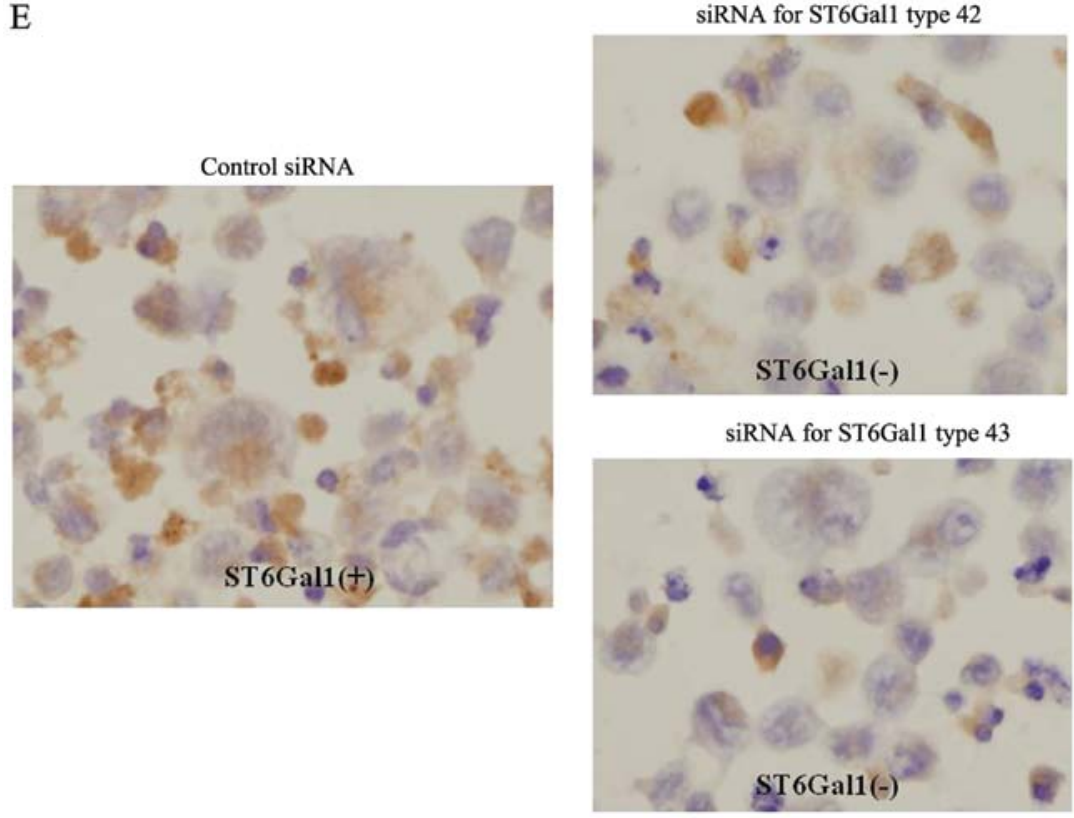

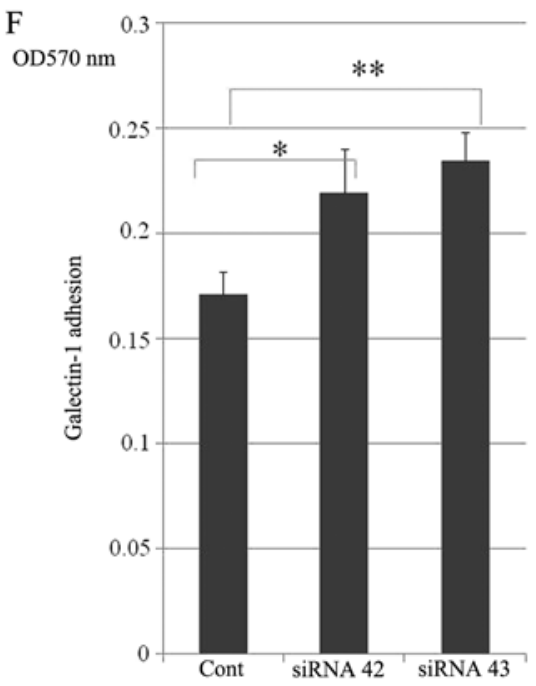

Figure 1. Continued. On resialylation assay, ST6Gall enhanced cell adhesion to WGA, and inhibited the desialyated H-ALCL cells binding capacity to L-PHA lectin and galectin-1 $\left({ }^{*} \mathrm{P}=0.003 ;{ }^{* *} \mathrm{P}=0.002 ;{ }^{* * *} \mathrm{P}=0.01\right)$ (D). On knockdown experiments, expression of ST6Gall on the cytoplasm of H-ALCL cells immunohistochemically (E) and knockdown of ST6Gall dramatically enhanced cell adhesion to galectin- $\left({ }^{*} \mathrm{P}=0.018 ;{ }^{* *} \mathrm{P}=0.0017\right)(\mathrm{F})$. Representative results from two or three independent experiments in triplicate are shown. protein tyrosine phosphatase (PTP) activity by the CD45 PTP drug discovery kit, AK-812 (Biomol) according to the manufacturer's instructions with modification. For analysis, the cell lysate was prepared by $1 \%$ NP-40 PBS buffer. The PTP inhibitor, sodium orthovanadate (V) (vanadate) (Wako, Japan) treatment was performed at $100 \mu \mathrm{M}$ for $16 \mathrm{~h}$ at $37^{\circ} \mathrm{C}$ using H-ALCL cell line for cell death analysis, and $400 \mu \mathrm{M}$ for $2 \mathrm{~h}$ for CD45 PTP activity analysis. The inhibition of CD45 activity by vanadate was validated on CD45 activity assay using pure CD45 protein mixed with vanadate (data not shown).

\section{Results}

Sialylation and cell adhesion assay. Treatment of neuraminidase which cleaves cell surface sialic acid enhanced PNA, HPA and L-PHA lectin reactivity suggesting that neuraminidase removes cell surface sialic acid from $\mathrm{O}$ - and $\mathrm{N}$-glycans (Fig. 1A). Treatment of neuraminidase from Arthrobacter ureafaciens markedly enhanced cell adhesion to galectin-1 (using galaptin) (Fig. 1B). Treatment of neur- 
A
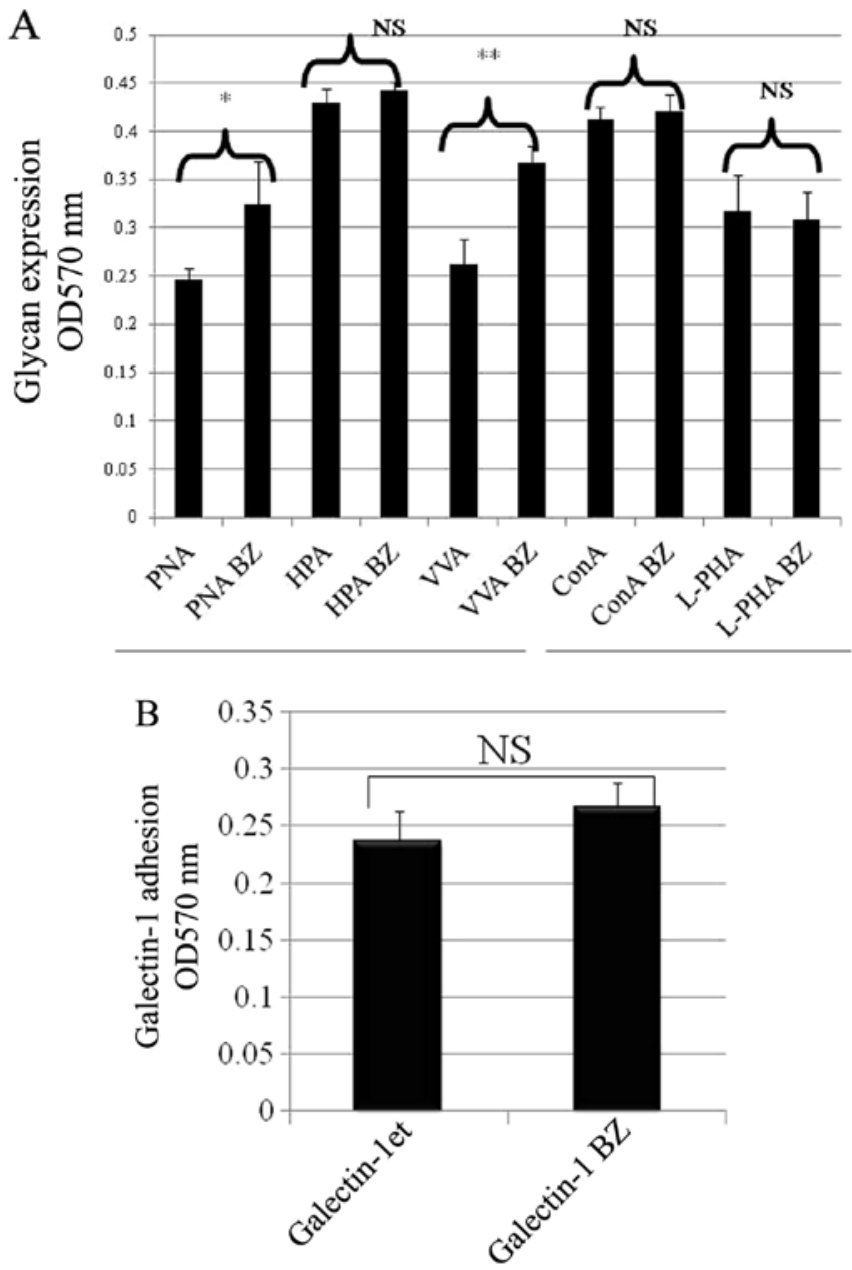

Figure 2. O-glycosylation inhibitor, benzyl-GalNAc (BZ) treatment resulted in the enhancement of PNA and VVA lectin reactivity suggesting the inhibition of elongation of O-glycosylation (PNA, ${ }^{*} \mathrm{P}<0.05$; VVA, ${ }^{* *} \mathrm{P}<0.005$; NS, not significant) (A). ConA and L-PHA lectin binding activity which is related to N-glycans was not dramatically changed. Treatment of BZ did not show alteration of cell adhesive capacity to human recombinant galectin-1 (NS, not significant; et, ethanol control; BZ, benzyl-GalNAc) (B). Representative results from two independent experiments in triplicate are shown.

aminidase from Arthrobacter ureafaciens markedly enhanced cell adhesion to galectin-1 (using recombinant galectin-1). Treatment of neuraminidase from Newcastle disease virus inhibited cell adhesion to galectin-1 and $\alpha 2,3$-neuraminidase did not enhance cell adhesion to galectin-1 (Fig. 1C). On resialylation assay, ST6Gall enhanced cell adhesion to WGA, and inhibited the desialyated H-ALCL cell binding capacity to L-PHA lectin and galectin-1 (Fig. 1D). On knockdown experiments, ST6Gall dramatically disappeared in the cytoplasm of H-ALCL cells and knockdown of ST6Gall enhanced cell adhesion to galectin-1 (Fig. 1E and F).

O-glycosylation inhibitor and cell adhesion assay. O-glycosylation inhibitor, benzyl-GalNAc (BZ) treatment resulted in the enhancement of PNA and VVA lectin reactivity suggesting the inhibition of elongation of O-glycosylation (Fig. 2A). ConA and L-PHA lectin binding activity which is related to $\mathrm{N}$-glycans was not dramatically changed. Treatment of BZ did not show alteration of cell adhesive capacity to human recombinant galectin-1 (Fig. 2B).

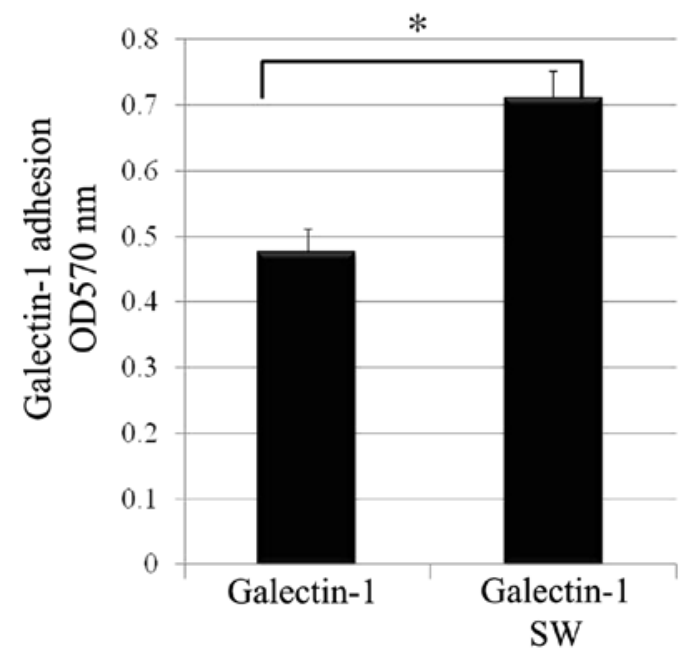

Figure 3. Treatment of SW markedly enhanced the cell adhesive capacity to human recombinant galectin $-1\left({ }^{*} \mathrm{P}=0.000893\right)$. Representative results from two independent experiments in triplicate are shown.

$N$-glycosylation inhibitor and adhesion assay. Treatment of SW markedly enhanced the cell adhesive capacity to human recombinant galectin-1 (Fig. 3).

Glycomic analysis on galectin-1 cell adhesion assay. Briefly the H-ALCL cells were treated with neuraminidase from AU. Then the H-ALCL cells were treated with PNA, Jacalin, SBA, HPA, VVA, UEA-1, WGA, L-PHA, E-PHA and DSA lectins and these lectins modulate the adhesive properties to galectin-1 of H-ALCL cells (Fig. 4).

Sialylation regulates cell invasion through galectin-1. Treatment of neuraminidase markedly inhibited cell invasive capacity to galectin-1 (Fig. 5).

Galectin-1 and ST6Gall expression. H-ALCL cells showed galectin-1 expression in the cytoplasm (Fig. 6A). Galectin-1 was produced in autocrine fashion in H-ALCL cell line (Fig. 6B). ST6Gall was expressed in the cytoplasm of H-ALCL cells (Fig. 6C).

Effect of wortmannin, PD98059, cytochalasin B and Rho inhibitor. The amount of cell adhesion of H-ALCL cells was inhibited by treatment of wortmannin (Fig. 7A). The amount of cell invasive capacity was inhibited by treatment of wortmannin and PD98059 (Fig. 7B). The amount of cell adhesion of H-ALCL cells was enhanced by treatment of cytochalasin B (Fig. 7C). The amount of cell invasion to galectin-1 was dramatically inhibited by treatment of cytochalasin B (Fig. 7D). The amount of cell invasion to galectin-1 was dramatically inhibited by treatment of Rho inhibitor, C3 transferase (Fig. 7E).

Cell death induction by galectin-1 and CD45PTP. Measurement of viable cells by trypan-blue exclusion method revealed the number of H-ALCL cells decreased with galectin-1 treatment after 3 days (Fig. 8A). On treatment with $20 \mu \mathrm{M}$ galectin-1 for $1 \mathrm{~h}$, the CD45 PTP activity was inhibited 


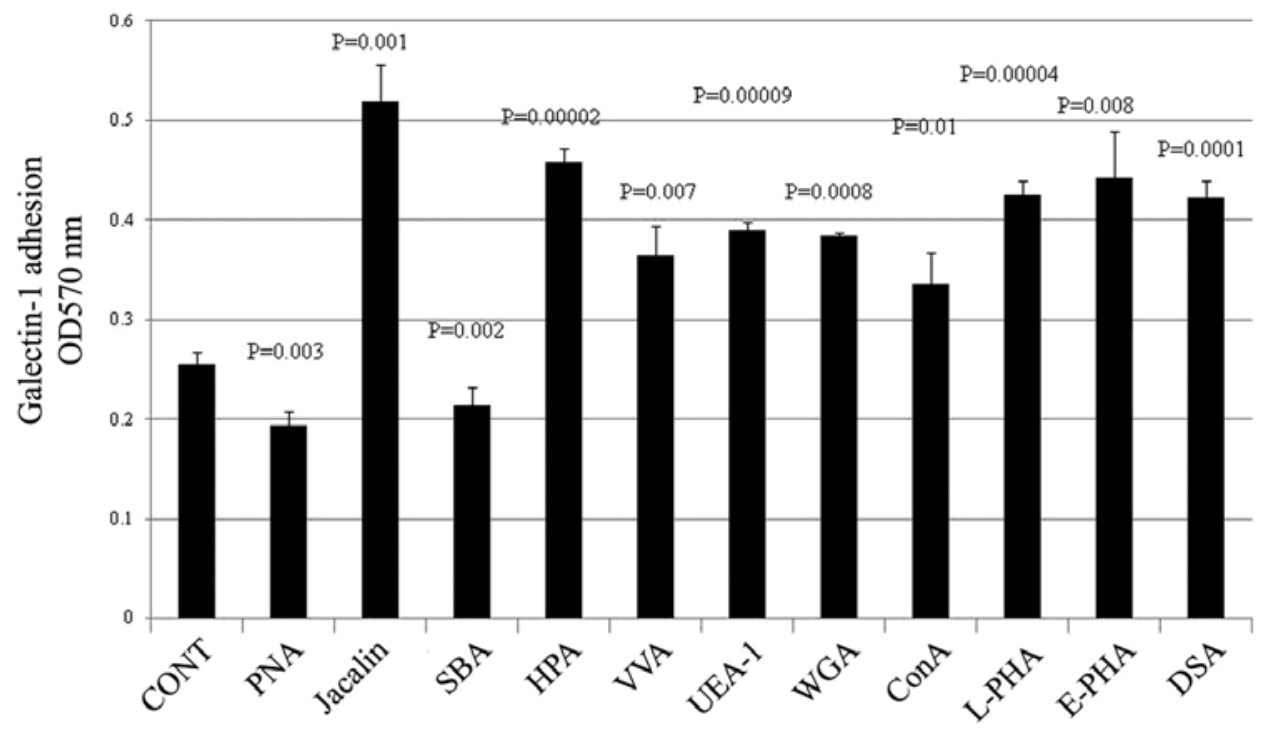

Figure 4. The H-ALCL cells were treated with neuraminidase from AU. The H-ALCL cells were treated with PNA, Jacalin, SBA, HPA, VVA, UEA-1, WGA, L-PHA, E-PHA and DSA lectins and these lectins modulate the adhesive properties to galectin- 1 of H-ALCL cells ( $P N A, P=0.003$; Jacalin, $\mathrm{P}=0.001$; SBA, P=0.002; HPA, P=0.00002; VVA, P=0.0075; UEA-1, P=0.00009; WGA, P=0.0008; L-PHA, P=0.00004; E-PHA, P=0.008; DSA, P=0.0001; NS, not significant). Representative results from two independent experiments in triplicate are shown.

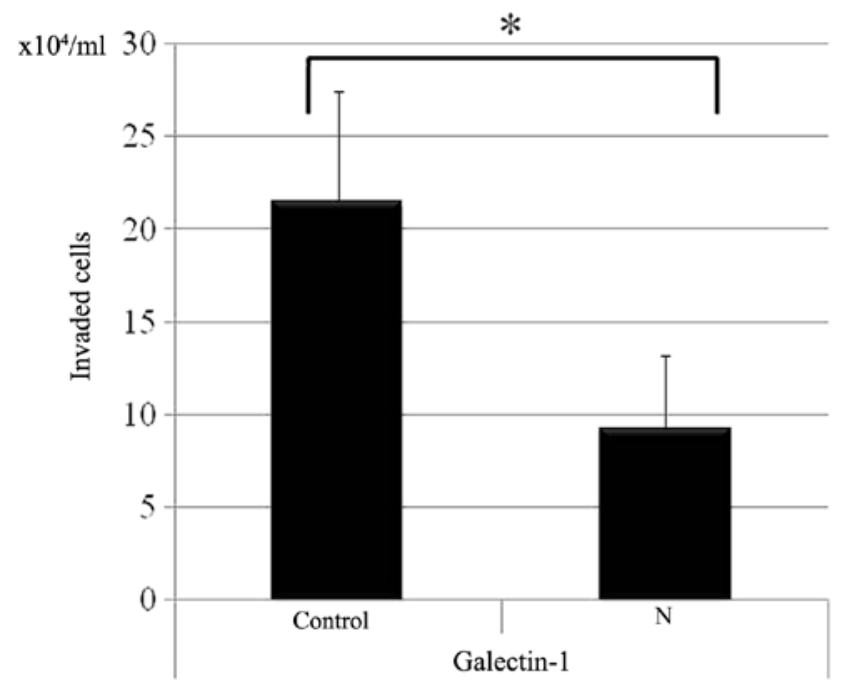

Figure 5. Cell invasion assay for galectin-1. The treatment of neuraminidase $(\mathrm{N})$ inhibited cell invasive capacity of galectin-1 ( $\mathrm{P}=0.008828)$. Representative results from two independent experiments in triplicate are shown.

(Fig. 8B). Vanadate can completely inhibit the recombinant CD45 PTP activity (data not shown). Treatment with vanadate inhibited CD45 PTP activity after $2 \mathrm{~h}$ at a concentration of $400 \mu \mathrm{M}$ (Fig. 8C) and induced cell death in H-ALCL cell line after $16 \mathrm{~h}$ at a concentration of $100 \mu \mathrm{M}$ (Fig. 8D).

\section{Discussion}

Galectin-1 acts as extracellular matrix (6) as well as a modulator of cell adhesion and invasion to extracellular matrix in tumor cell lines (11-14). The present data suggested that cell surface sialylation may inhibit cell adhesion to galectin-1 in H-ALCL cells and suggested that cell surface desialylation resulted in enhancement of cell adhesion to galectin-1 and reduction in cell invasion through galectin-1. Previously we reported that $\alpha 2,6$-linked sialic acid is involved in masking effect on interaction between galectin-1 and cell surface glycans $(7,15)$. In the present study $\alpha 2,6$-linked sialic acid is similarly involved. The data confirmed $\alpha 2,6$-linked sialic acid is able to modulate interactions between galectin-1 and cell surface glycans in human lymphoma. On the other hand, the neuraminidase from NDV which can cleave $\alpha 2,3,2,8,2$,9-linked sialic acids, not 2,6-linked, inhibited degree of cell adhesion to galectin-1. The $\alpha 2,3$ neuraminidase did not enhance cell adhesion to galectin-1. Therefore, taken together, $\alpha 2,6$-linked sialic acids may be essential to inhibit cell adhesion to galectin-1. Several recent reports suggested that $\alpha 2,3$-linked sialic acid also may be associated with tumor metastasis $(16,17)$. In future investigations we will clarify biological functions of $\alpha 2,3$-linked sialic acid in malignant lymphoma. Furthermore, the H-ALCL cells expressed ST6Gal1 in the cytoplasm, and neuraminidase treatment enhanced cell adhesion to L-PHA lectin and the $\alpha 2,6$-linked sialylation by ST6Gal1 resulted in inhibition of cell adhesion to L-PHA lectin suggesting that ST6Gal1 resialylates the terminal galactose residue of $\mathrm{N}$-glycans. Treatment with ST6Gal1 inhibits cell adhesion to galectin-1 suggesting that $\alpha 2,6$-linked sialylation of terminal residue of N-glycans by ST6Gall inhibits cell adhesion to galectin-1. The data are consistent with our previous reports using DLBCL cell line, HBL-2, as described above (7). Therefore, $\alpha 2,6$-sialylation of cell surface glycans may be associated with inhibitory effect of cell adhesion to galectin-1 regardless of histological types of human lymphoma cells. $\alpha 2,6$-sialylation by ST6Gal1 is expressed in colon cancer tissues compared to that of normal tissue and expression of ST6Gall is correlated to the high risk group in pediatric acute leukemia $(18,19)$. $\alpha 2,6$-sialylation of tumor cells may be associated with carcinogenesis in colon cancer cells. ST6Gall is reported to be secreted into cell culture media (20). In our speculation a soluble form of 
A

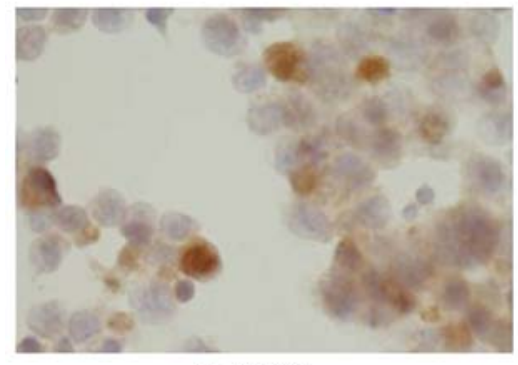

H-ALCL

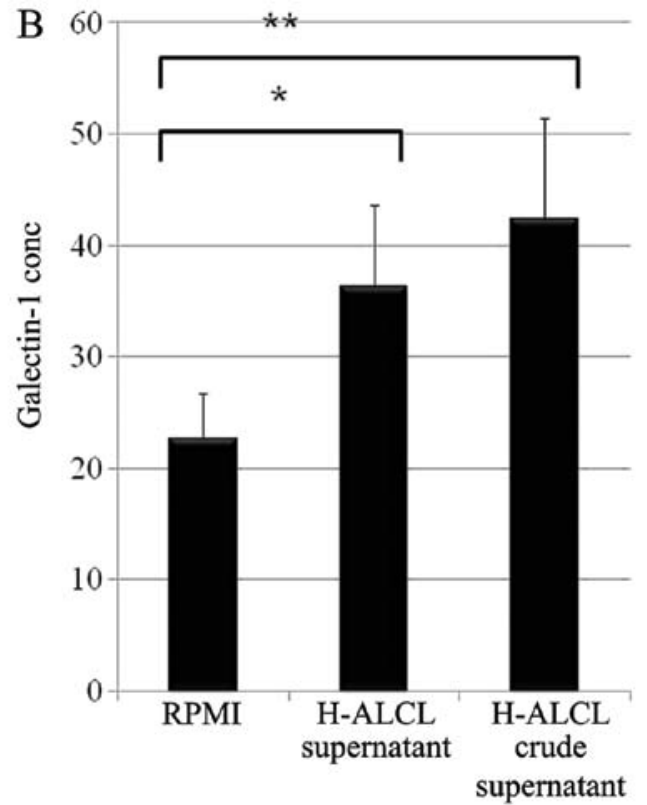

been published. This is the first report that galectin-1 affects cell adhesion or invasion as extracellular matrix in ALCL.

The CD45 is a candidate glycoprotein of galectin-1 receptor (22). In our preliminary data from the antibody inhibition assay, we demonstrated that anti-CD30, CD 45, CD45RO and EMA (one of galectin-3 receptors) antibodies enhanced cell adhesion to galectin-1 suggesting that these antibodies possess agonistic effects and the protein portions of ALK, CD30, CD45, CD45RO and EMA molecules may contribute to galectin-1 mediated cell adhesion. There is a possibility that the protein portions of glycoproteins can affect interaction between galectin-1 and cell surface glycoproteins.

On the kinase inhibitor analysis, wortmannin showed complete inhibition of cell adhesion to galectin-1, and PD98059 showed marked inhibition of invasion to galectin-1. The PI3K is known to regulate cell adhesion (23) and the MAPK is known to regulate cell migration (24). Therefore, PI3K may regulate the galectin-1-mediated cell adhesion and MAPK may regulate the galectin-1-mediated cell migration in H-ALCL cells. As cytochalasin B disrupts polymerization of actin which is a cytoskeleton, effect of cytochalasin B on cell adhesion to galectin-1 implies that cell adhesion to galectin-1 may be mediated by actin polymerization in H-ALCL cells. Rho (Ras homologue gene family member) is a protein which is associated with lymphocyte migration (25). In our present data Rho inhibitor, C3-transferase dramatically inhibits cell invasion through galectin-1. Rho may be a candidate regulator for cell migration of H-ALCL cells contacting galectin-1.

Sialylation was reported to regulate interaction between galectin-3 and ligand in tumor cells and the mechanisms are crucial in regulating adhesive and de-adhesive events in the invasive capacity of metastatic cells (26). We hypothesized that the masking effect of ligand by sialylation may be important in cell adhesion and invasion to galectins which are known to deposit in the tumor environment. Sialylation may act as switch on/off mechanism in the interaction between galectin and its oligosaccharide ligands. This hypothesis may provide a new scientific foundation in understandings the mechanisms 

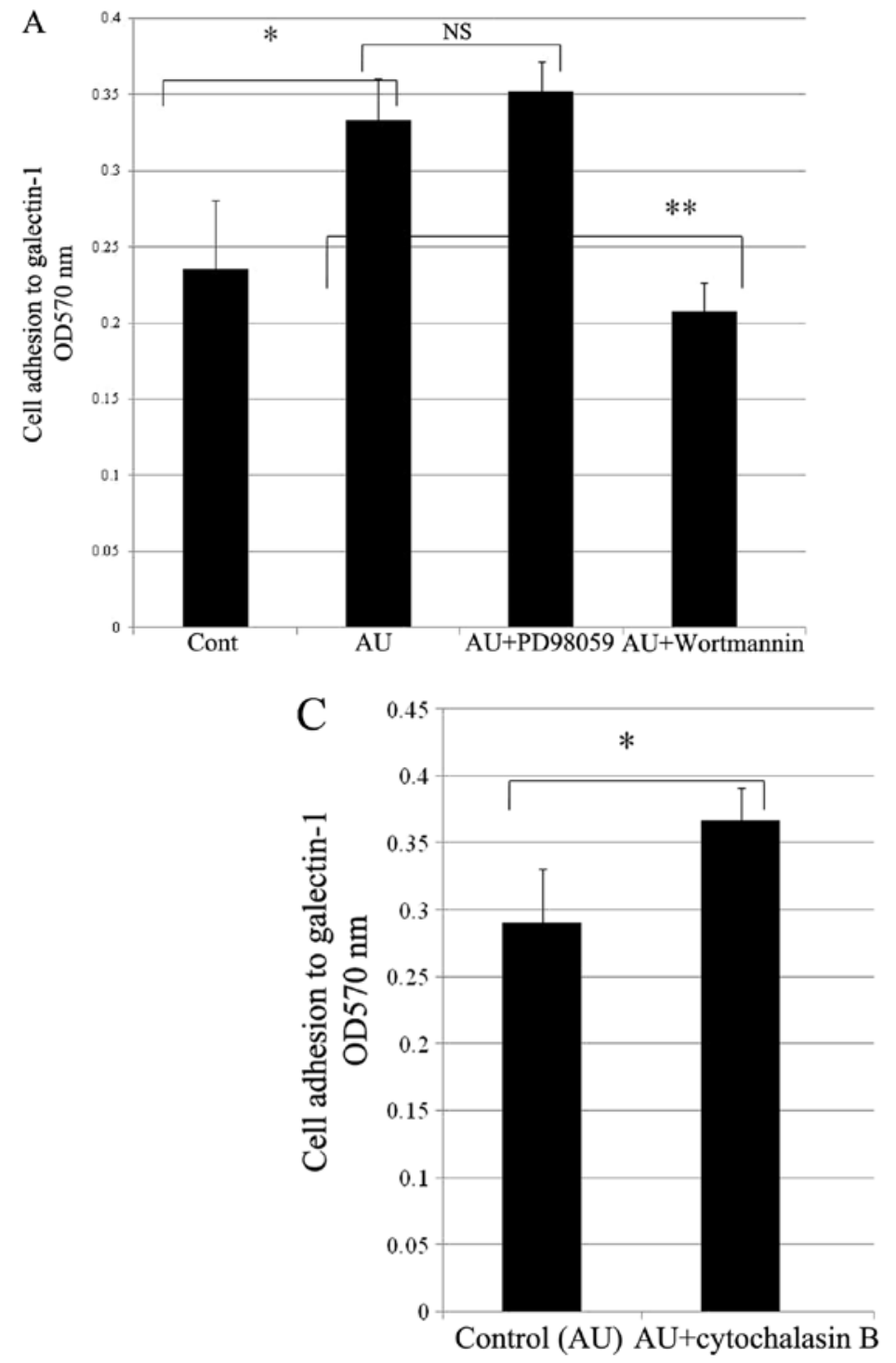

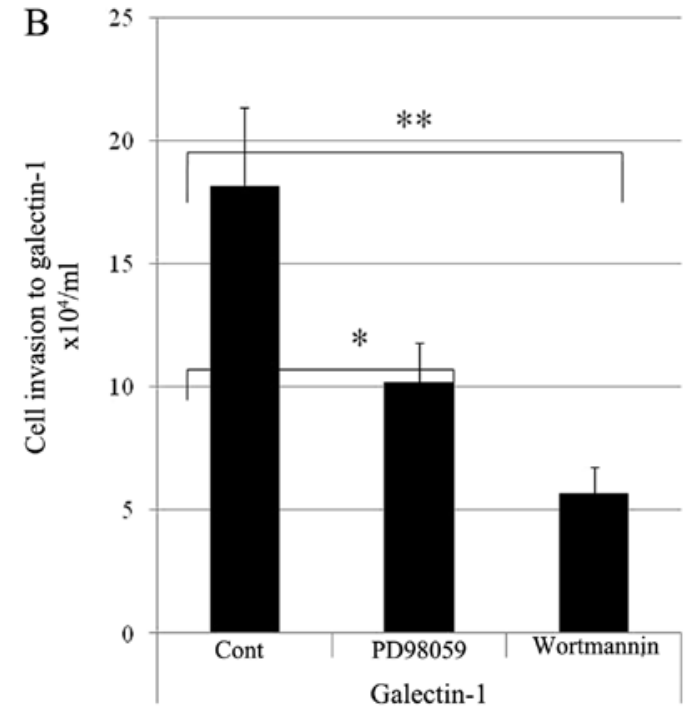

$\mathrm{D}$

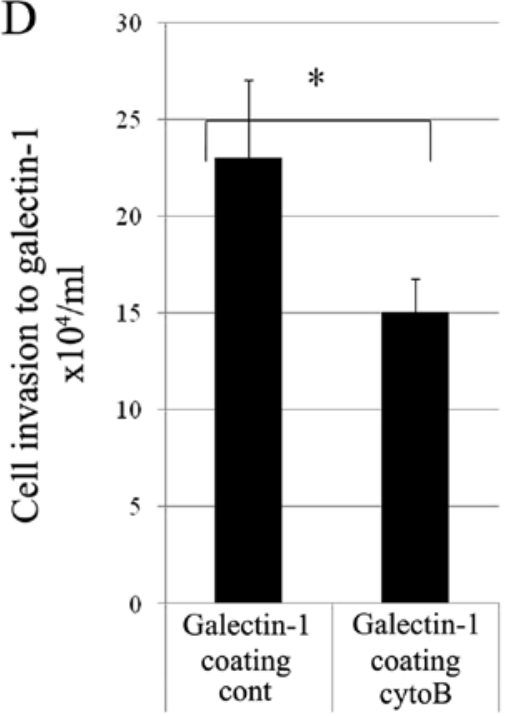

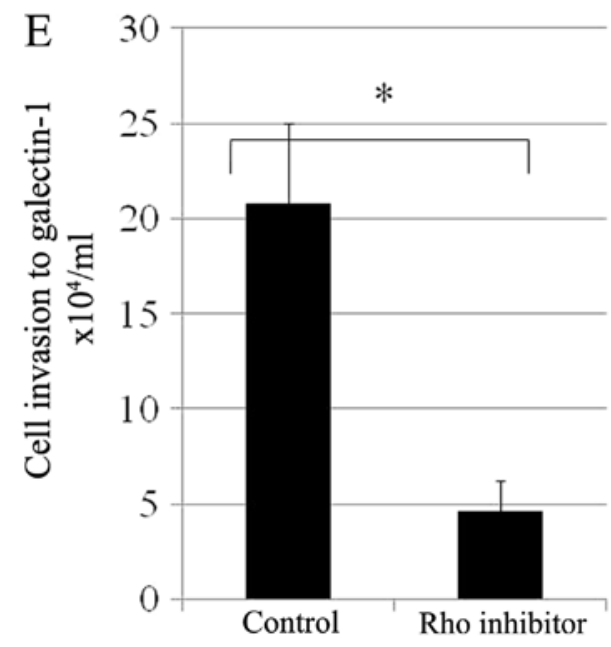

Figure 7. Effect of wortmannin, PD98059, cytochalasin B and Rho inhibitor. The amount of cell adhesion of H-ALCL cells was inhibited by wortmannin treatment $\left({ }^{*} \mathrm{P}=0.02 ;{ }^{* *} \mathrm{P}=0.002\right)(\mathrm{A})$. The amount of cell invasive capacity was inhibited by treatment of PD98059 and wortmannin $\left({ }^{*} \mathrm{P}=0.01\right.$; $\left.{ }^{* *} \mathrm{P}=0.0069\right)(\mathrm{B})$. The amount of cell adhesion of H-ALCL cells was enhanced by cytochalasin $\mathrm{B}$ treatment $\left({ }^{*} \mathrm{P}=0.029\right)(\mathrm{C})$. The amount of cell invasion to galectin-1 was dramatically inhibited by treatment of cytochalasin $B$ ( $\mathrm{P}=0.028)(\mathrm{D})$. The amount of cell invasion to galectin-1 was dramatically inhibited by Rho inhibitor, $\mathrm{C} 3$ transferase treatment $\left({ }^{*} \mathrm{P}=0.006\right)(\mathrm{E})$. The data are representative of at least two independent experiments in triplicate. of lymphoma cell biology, especially lymphoma cell adhesion and invasion.

Treatment of SW, a potent $\mathrm{N}$-glycosylation inhibitor showed marked enhancement of cell adhesive capacity to galectin-1 suggesting that mature $\mathrm{N}$-glycans which have sialylated glycans inhibit cell adhesion to galectin-1 in ALCL. Previously, we reported that SW treatment showed enhancement of lymphoma cells to galectin-1 in the human diffuse large B cell lymphoma cell line HBL-2 (7). Collectively, these data suggest that cell surface $\mathrm{N}$-glycans can modulate cell adhesive capacity to galectin-1 in lymphoma cells, regardless of histological subtypes.

In eukaryotic cells the glycans mathematically show more than one million structures and due to this complexity the glycomic analysis is required to glycobiological investigation (27). In the present glycomics analysis, cell adhesion to galectin-1 was modulated by several types of lectin blocking suggesting that galectin-1-mediated cell adhesion may be regulated by several types of glycans as well as $\beta$-galactose residue. PNA, Jacalin, SBA, HPA, VVA, UEA-1, WGA, L-PHA, E-PHA and DSA lectin blocking showed modulation of cell adhesive properties to galectin-1. These findings may be supported by the hypothesis that several cell surface glycans 
A

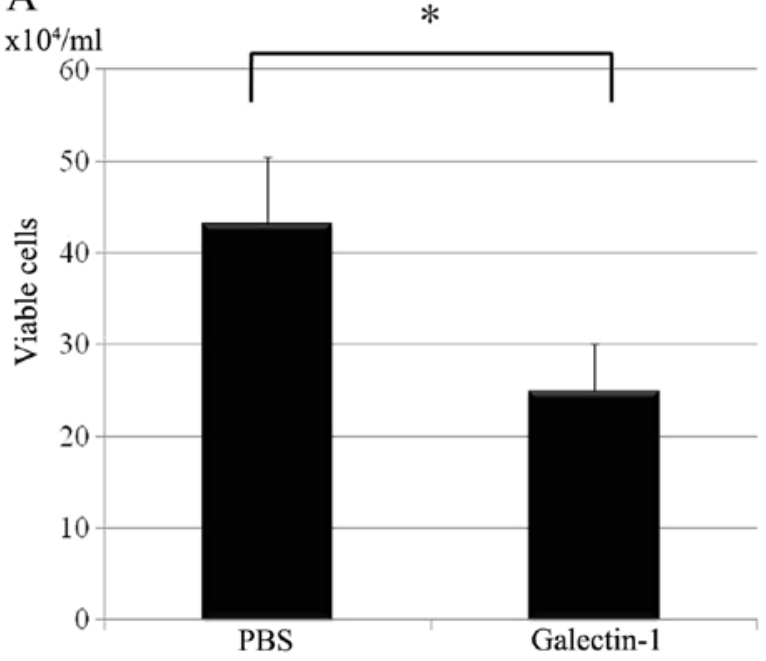

$\mathrm{B}$

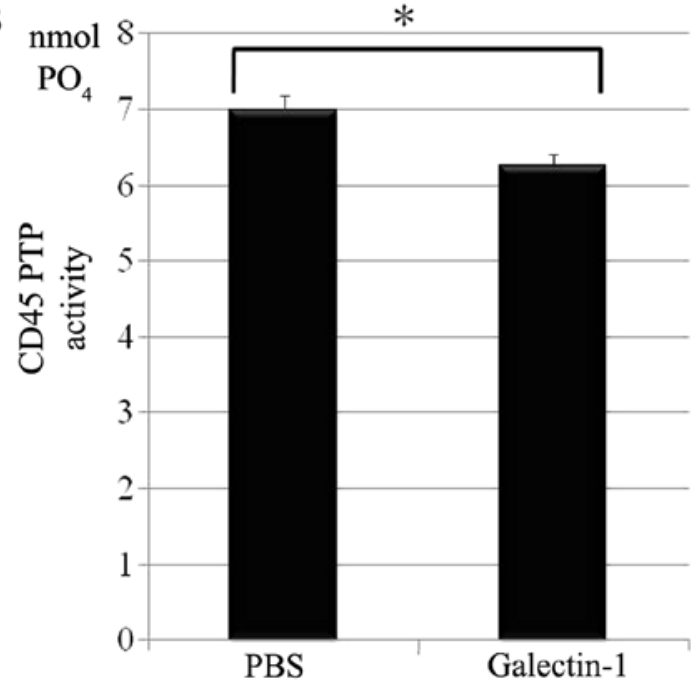

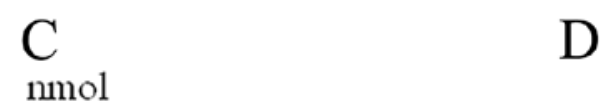

$\mathrm{PO}_{4}$

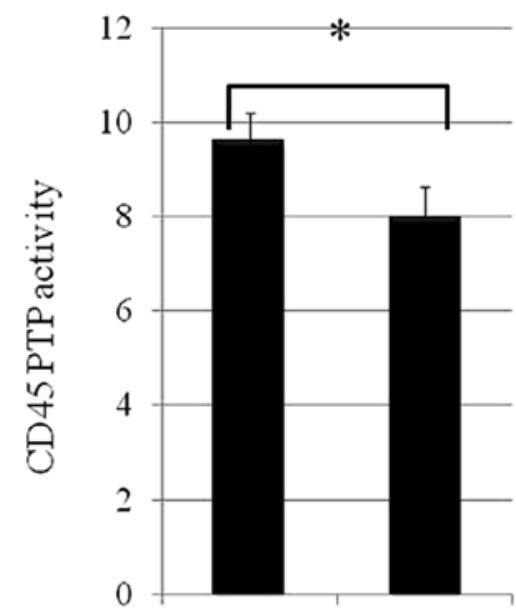

$\mathrm{x} 10^{4} / \mathrm{ml}$
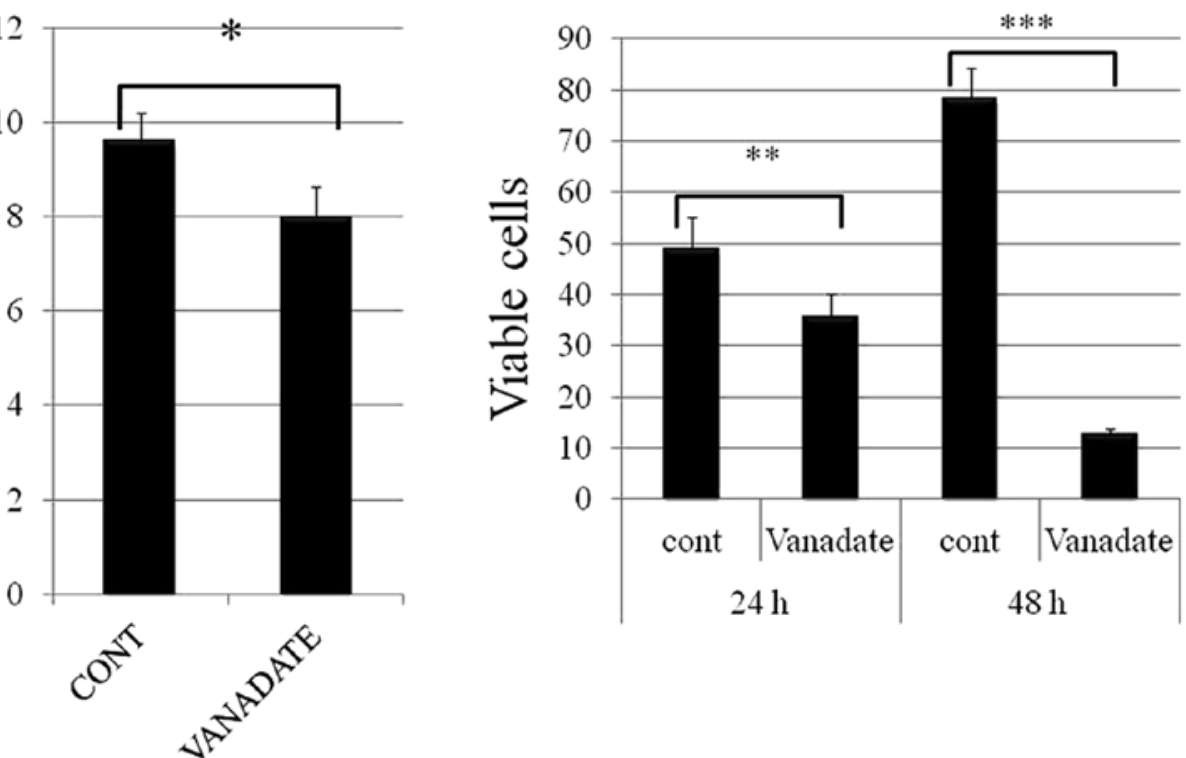

Figure 8. Cell death induction by galectin-1 and CD45PTP. (A) Cell death induction by galectin-1. Measurement of viable cells by trypan-blue exclusion methods revealed the number of H-ALCL cells decreased with galectin-1 treatment ( $\mathrm{P}=0.0014427)$. Representative results from two independent experiments in triplicate are shown. (B) CD45 PTP activity assay. In treatment with $20 \mu \mathrm{M}$ galectin-1 for $1 \mathrm{~h}$ inhibited the CD45 PTP activity ("P=0.003043). PO ${ }_{4}, \mathrm{CD}_{4} 45$ mediated release $\mathrm{PO}_{4}$ from unknown phosphoproteins. The data are representative of two independent experiments. (C) PTP inhibition assay. Treatment with vanadate inhibited CD45 PTP activity after $2 \mathrm{~h}$ at a concentration of $400 \mu \mathrm{M}\left({ }^{*} \mathrm{P}=0.016098\right.$; CONT, control experiment with PBS). (D) Treatment with vanadate induced cell death in H-ALCL cell line after 24 or $48 \mathrm{~h}$ at a concentration of $100 \mu \mathrm{M}\left({ }^{*} \mathrm{P}=0.021151 ; * * \mathrm{P}=0.000965\right)$. The data are representative of two independent experiments in triplicate.

may interfere with $\beta$-galactose by physical disturbance, such as steric hindrance. PNA and SBA lectin reactive $\beta$-galactose may be a receptor for galectin-1. On the other hand, the glycans reactive for Jacalin, UEA-1, WGA, ConA, L-PHA, E-PHA and DSA lectins may interfere the binding activity of H-ALCL cell to galectin-1 by steric hindrance. The steric hindrance by several different glycans may modulate cell adhesive properties to galectin-1. This may be a new concept of the extremely complex glycobiology.

In Hodgkin lymphoma galectin-1 is a predictive marker for evaluation of prognosis of the patients (28). The expression of galectin-1 is reported and galectin-1 may facilitate the immunosuppressive microenvironment $(29,30)$. Previously some reports show that galectin-1 can induce apoptosis in T cells (18) and tumor galectin- 1 suppresses T cell immunity through induction of apoptosis of T cells (31). Galectin-1 induced cell death is caspase-independent (32), and in our preliminary data, the cell death induced by galectin-1 in H-ALCL was caspaseindependent (data not shown). In the present study galectin-1 induced cell death after $72 \mathrm{~h}$. In other research, the expression of galectin-1 in ALCL and caspase-dependent apoptosis induction by galectin-1 was reported recently (1). The data 
implies that galectin-1 is a useful tool for therapy of ALCL. The galectin-1 receptor, CD45PTP activity was inhibited by treatment with galectin-1 in H-ALCL cells. The data are consistent with the previous reports showing the interaction between galectin-1 and CD45 in Burkitt's lymphoma cell line (33). Our present report is the first showing interaction between galectin-1 and CD45PTP activity in ALCL cells.

\section{Acknowledgements}

We are grateful to Ms. M. Satoh and Mrs. H. Kaneko for their technical assistant and advice.

\section{References}

1. Suzuki O, Hirsch B, Abe M, Dürkop H and Stein H: Galectin-1mediated cell death is increased by CD30-induced signaling in anaplastic large cell lymphoma cells but not in Hodgkin lymphoma cells. Lab Invest 92: 191-199, 2012.

2. Suzuki O, Nozawa Y and Abe M: Regulatory roles of altered Nand $\mathrm{O}$-glycosylation of CD45 in galectin-1-induced cell death in human diffuse large B cell lymphoma. Int J Oncol 26: 1063-1068, 2005.

3. Earl LA, Bi S and Baum LG: N- and O-glycans modulate galectin-1 binding, CD45 signaling, and T cell death. J Biol Chem 285: 2232-2244, 2010.

4. Rabinovich GA, Rubinstein N and Toscano MA: Role of galectins in inflammatory and immunomodulatory processes. Biochim Biophys Acta 1572: 274-284, 2002.

5. Allen HJ, Sucato D, Gottstine S, Kisailus E, Nava H, Petrelli N, Castillo $\mathrm{N}$ and Wilson D: Localization of endogenous betagalactoside-binding lectin in human cells and tissues. Tumor Biol 12: $52-60,1991$

6. Skrincosky DM, Allen HJ and Bernacki RJ: Galaptin-mediated adhesion of human ovarian carcinoma A121 cells and detection of cellular galaptin-binding glycoproteins. Cancer Res 53: 2667-2675, 1993.

7. Suzuki O, Nozawa Y and Abe M: The regulatory roles of cell surface sialylation and $\mathrm{N}$-glycans in human B cell lymphoma cell adhesion to galectin-1. Int J Oncol 28: 155-160, 2006.

8. Landemarre L, Cancellieri P and Duverger E: Cell surface lectin array: parameters affecting cell glycan signature. Glycoconj J 30: 195-203, 2013.

9. Suzuki O, Nozawa Y, Kawaguchi T and Abe M: Phaseolus vulgaris leukoagglutinationg lectin-binding reactivity in human diffuse large B cell lymphoma and its relevance to the patient's clinical outcome: lectin histochemistry and lectin blot analysis. Pathol Int 49: 874-880, 1999.

10. Albini A, Iwamoto Y, Kleinman HK, Martin GR, Aaronson SA, Kozlowski JM and McEwan RN: A rapid in vitro assay for quantitating the invasive potential of tumor cells. Cancer Res 47: 3239-3245, 1987.

11. Horiguchi N, Arimoto K, Mizutani A, Endo-Ichikawa Y, Nakada $\mathrm{H}$ and Taketani S: Galectin-1 induces cell adhesion to the extracellular matrix and apoptosis of non-adherent human colon cancer Colo201 cells. J Biochem 134: 869-874, 2003.

12. Espelt MV, Croci DO, Bacigalupo ML, Carabias P, Manzi M, Elola MT, Muñoz MC, Dominici FP, Wolfenstein-Todel C, Rabinovich GA and Troncoso MF: Novel roles of galectin-1 in hepatocellular carcinoma cell adhesion, polarization, and in vivo tumor growth. Hepatology 53: 2097-2106, 2011.

13. Sanchez-Ruderisch H, Detjen KM, Welzel M, André S, Fischer C, Gabius HJ and Rosewicz S: Galectin-1 sensitizes carcinoma cells to anoikis via the fibronectin receptor $\alpha 5 \beta 1$-integrin. Cell Death Differ 18: 806-816, 2011.

14. Zhao XY, Chen TT, Xia L, Guo M, Xu Y, Yue F, Jiang Y, Chen GQ and Zhao KW: Hypoxia inducible factor-1 mediates expression of galectin-1: the potential role in migration/invasion of colorectal cancer cells. Carcinogenesis 31: 1367-1375, 2010.
15. Zhuo Y and Bellis SL: Emerging role of alpha2,6-sialic acid as a negative regulator of galectin binding and function. J Biol Chem 286: 5935-5941, 2011.

16. Cui H, Lin Y, Yue L, Zhao X and Liu J: Differential expression of the $\alpha 2,3$-sialic acid residues in breast cancer is associated with metastatic potential. Oncol Rep 25: 1365-1371, 2011.

17. Wang FL, Cui SX, Sun LP, Qu XJ, Xie YY, Zhou L, Mu YL, Tang W and Wang YS: High expression of alpha 2, 3-linked sialic acid residues is associated with the metastatic potential of human gastric cancer. Cancer Detect Prev 32: 437-443, 2009.

18. Dall'Olio F, Chiricolo M, Ceccarelli C, Minni F, Marrano D and Santini D: Beta-galactoside alpha2,6 sialyltransferase in human colon cancer: contribution of multiple transcripts to regulation of enzyme activity and reactivity with Sambucus nigra agglutinin. Int J Cancer 88: 58-65, 2000.

19. Mondal S, Chandra S and Mandal C: Elevated mRNA level of hST6Gal I and hST3Gal V positively correlates with the high risk of pediatric acute leukemia. Leuk Res 34: 463-470, 2010.

20. Lee M, Park JJ, Ko YG and Lee YS: Cleavage of ST6Gal I by radiation-induced BACE1 inhibits golgi-anchored ST6Gal I-mediated sialylation of integrin $\beta 1$ and migration in colon cancer cells. Radiat Oncol 7: 47, 2012.

21. Suzuki O, Nozawa Y, Kawaguchi T and Abe M: UDP-GlcNAc2epimerase regulates cell surface sialylation and cell adhesion to extracellular matrix in Burkitt's lymphoma. Int J Oncol 20: 1005-1011, 2002.

22. Perillo NL, Pace KE, Seilhamer JJ and Baum LG: Apoptosis of T cells mediated by galectin-1. Nature 378: 736-739, 1995.

23. Yamamoto H, Nishi N, Shoji H, Itoh A, Lu LH, Hirashima M and Nakamura T: Induction of cell adhesion by galectin- 8 and its target molecules in Jurkat T-cells. J Biochem 143: 311-324, 2008.

24. Huang C, Jacobson K and Schaller MD: MAP kinases and cell migration. J Cell Sci 117: 4619-4628, 2004.

25. Tybulewicz VL and Henderson RB: Rho family GTPases and their regulators in lymphocytes. Nat Rev Immunol 9: 630-644, 2009.

26. de Oliveira JT, de Matos AJ, Santos AL, Pinto R, Gomes J, Hespanhol V, Chammas R, Manninen A, Bernardes ES, Albuquerque Reis C, Rutteman G and Gärtner F: Sialylation regulates galectin-3/ligand interplay during mammary tumour progression - a case of targeted uncloaking. Int J Dev Biol 55: 823-834, 2011.

27. Varki A, Cummings RD, Esko JD, et al: Glycomics. In: Essentials of Glycobiology. 2nd edition. Cold Spring Harbor Laboratory Press, Cold Spring Harbor, NY, 2009.

28. Kamper P, Ludvigsen M, Bendix K, Hamilton-Dutoit S, Rabinovich GA, Møller MB, Nyengaard JR, Honoré B and d'Amore F: Proteomic analysis identifies galectin-1 as a predictive biomarker for relapsed/refractory disease in classical Hodgkin lymphoma. Blood 117: 6638-6649, 2011.

29. Rodig SJ, Ouyang J, Juszczynski P, Currie T, Law K, Neuberg DS, Rabinovich GA, Shipp MA and Kutok JL: AP1-dependent galectin-1 expression delineates classical Hodgkin and anaplastic large cell lymphomas from other lymphoid malignancies with shared molecular features. Clin Cancer Res 14: 3338-3344, 2008.

30. Juszczynski P, Ouyang J, Monti S, Rodig SJ, Takeyama K, Abramson J, Chen W, Kutok JL, Rabinovich GA and Shipp MA: The AP1-dependent secretion of galectin-1 by Reed Sternberg cells fosters immune privilege in classical Hodgkin lymphoma. Proc Natl Acad Sci USA 104: 13134-13139, 2007.

31. Banh A, Zhang J, Cao H, Bouley DM, Kwok S, Kong C, Giaccia AJ, Koong AC and Le QT: Tumor galectin-1 mediates tumor growth and metastasis through regulation of T-cell apoptosis. Cancer Res 71: 4423-4431, 2011.

32. Hahn HP, Pang M, He J, Hernandez JD, Yang R-Y, Li L, Wang X, Liu F-T and Baum LG: Galectin-1 induces nuclear translocation of endonuclease $\mathrm{G}$ in caspase- and cytochrome c-independent T cell death. Cell Death Differ 11: 1277-1286, 2004.

33. Fouillit M, Joubert-Caron R, Poirier F, Bourin P, Monostori E, Levi-Strauss M, Raphael M, Bladier D and Caron M: Regulation of CD45-induced signaling by galectin-1 in Burkitt lymphoma B cells. Glycobiology 10: 413-419, 2000. 